\title{
Opleiden van dokters: er is meer dan competenties
}

Een belangrijk kenmerk van de modernisering van de medisch specialistische vervolgopleidingen is het competentiegericht opleiden. Hiervoor wordt in Nederland het CanMEDS competentiemodel gebruikt. ${ }^{1}$ Dit model wordt tevens de leidraad in de opleiding tot basisarts. Volgens het nieuwe Raamplan Artsopleiding dat in 2009 verschijnt, zal CanMEDS ook voor de initiële opleidingen richtinggevend zijn. Competenties zijn dus 'hot'. Maar er is meer dan competenties. Enigszins generaliserend kun je zeggen dat er drie factoren zijn die belangrijk zijn voor een goede opleiding: de student of arts in opleiding tot specialist (aios), de docent of opleider, en de leeromgeving. Ik licht deze factoren kort toe.

In een artikel van een paar jaar geleden in the New England Journal of Medicine werd aangetoond dat medisch specialisten die in aanraking kwamen met het tuchtcollege significant vaker in hun studententijd onprofessioneel gedrag hadden vertoond. ${ }^{2}$ Met andere woorden, het onprofessionele gedrag was achteraf mogelijk te voorspellen geweest. In het verlengde daarvan kun je stellen dat selectie van studenten op (on)professioneel gedrag dus mogelijk winst oplevert. In een aantal medische faculteiten bestaat ervaring met decentrale selectie. Onderzoek in Rotterdam, waar de grootste ervaring met decentrale selectie is, laat zien dat de uitval na het eerste jaar bij decentraal geselecteerde studenten aanzienlijk lager is dan bij de centraal ingelote studenten. ${ }^{3}$ Ofschoon er na het eerste jaar geen duidelijk gunstig effect van decentrale selec- tie meetbaar is - decentraal geselecteerde studenten hebben tijdens de studie veel extracurriculaire activiteiten - suggereren deze onderzoeksresultaten dat er met deze benadering geselecteerd wordt op motivatie. Andere faculteiten hebben het voorbeeld van Rotterdam gevolgd en laten inmiddels (maximaal) de helft van de studenten toe via dit selectieproces. Indien hierbij ook de vaardigheden op het gebied van non-cognitieve kwaliteiten van aspirant-studenten worden meegenomen, hetgeen de bedoeling is van de Groningse decentrale selectie die dit jaar voor het eerst zal plaatsvinden, kan zo'n selectie ertoe bijdragen dat we gemotiveerde studenten krijgen die in aanleg kwaliteiten in zich hebben die horen bij een goede dokter.

De tweede factor van belang voor een goede opleiding is de docent of opleider. Anders dan in vele andere onderwijsinstellingen worden aan de docenten van de universiteit en in het ziekenhuis nauwelijks eisen gesteld op het gebied van onderwijskundige vaardigheden. Gelukkig stelt het Centraal College Medische Specialismen nu duidelijke eisen aan opleiders. Er is zelfs sprake van dat het actief deelnemen van opleidingsteams aan onderwijskundige trainingen een kwaliteitsindicator kan zijn bij de beoordeling van de opleiding. Een goede ontwikkeling. Maar om eisen te kunnen stellen aan docenten en opleiders moet je ook trainingsprogramma's aanbieden. Teach-the-teacher cursussen, in eerste instantie bedoeld voor opleiders in de vervolgopleiding, rijzen als paddenstoelen uit de grond. Ofschoon dat een positieve ontwikkeling is, zal de 
komende jaren kwaliteitsbewaking van deze cursussen met accreditatie noodzakelijk zijn om de lat hoog te houden. Omdat veel docenten in de vervolgopleiding vaak ook docent in de initiële opleiding zijn, komt dit het gehele opleidingscontinuüm ten goede. Bij het aanbieden van cursussen en het stellen van eisen aan docenten hoort ook dat onderwijskwaliteit erkend wordt als een wezenlijk onderdeel van het takenpakket van de medisch specialist. Goed onderwijs moet net zoveel carrièrekansen bieden als goede patiëntenzorg of goed onderzoek. De NVMO-werkgroep Docentprofessionalisering heeft onlangs het profiel van docenten in de basisopleiding vastgesteld. ${ }^{4}$ Dit biedt goede aanknopingspunten voor een vergelijkbare profieldefinitie van de opleider in de vervolgopleiding. Daarnaast biedt het een goede kans voor een betere afstemming en integratie van trainingen en cursussen bedoeld voor de basisopleiding met die voor de vervolgopleiding.

De derde factor bij de goede opleiding is de leeromgeving. Het belang van kenmerken zoals veilig leerklimaat, levenslang leren, reflectie op eigen vorderingen, goede feedback door opleiders en de docent als rolmodel is duidelijk. Maar voor een goede leeromgeving is meer nodig en dat laat zich het best omschrijven als 'clinical governance'. Dit begrip is eind jaren '90 in Engeland geïntroduceerd en staat voor het borgen en verbeteren van klinische standaarden. ${ }^{5}$ In zijn voordracht 'Innovatie van medisch onderwijs en kwaliteit van zorg: de rol van clinical governance' tijdens het NVMO congres in 2007 heeft prof. dr. Erik Heineman het concept van clinical governance uitgebreid toegelicht. Van wezenlijk belang bij clinical governance is dat de verantwoordelijkheid voor de zorg niet meer uitsluitend bij de dokter ligt, maar dat dat iets is van de hele organisatie (ziekenhuis en faculteit).
Dat vereist een cultuurverandering waarbij professionaliteit niet alleen leerdoel is, maar ook zichtbaar is in de praktijk. Dat betekent bij voorbeeld dat als wij onze studenten een onvoldoende geven voor hun professioneel gedrag omdat zij altijd te laat komen, wij ook in ons zorgproces ervoor moeten zorgen dat de spreekuren op tijd lopen en de patiënt wordt gezien op het tijdstip dat is afgesproken. Clinical governance, waarin we aan studenten en aios laten zien hoe optimale zorg kan worden geboden, hoort daarom thuis in het rijtje van de kenmerken van een goede leeromgeving en draagt wezenlijk bij aan het opleiden van goede dokters.

Omdat dit het eerste Redactioneel van een nieuwe jaargang is, een aantal afsluitende opmerkingen van uw hoofdredacteur. In het afgelopen jaar hebben we ons in de redactie de vraag gesteld waar we met het TMO over vijf jaar willen staan. Natuurlijk moet het dan nog steeds het lijfblad van de NVMO zijn. Maar we vragen ons wel af of de huidige vorm zal blijven voldoen. Voor een Nederlandstalig tijdschrift als het TMO blijft de concurrentie met internationale Engelstalige tijdschriften moeilijk en soms frustrerend. De vraag is dan ook of het TMO zich de komende jaren niet zou moeten ontwikkelen tot een meer internationaal gericht Engelstalig tijdschrift. Als experiment op dit gebied zullen we één van de laatste nummers van deze jaargang als Engelstalig nummer uitbrengen, in samenwerking met de redactie van het Duitse Zeitschrift für Medizinische Ausbildung.

Een ander punt is de samenstelling van de redactie. In december jl. hebben we afscheid genomen van Roy Remmen. Roy heeft in de acht jaren dat hij lid was van de redactie op enthousiaste en kundige wijze bijgedragen aan het TMO. Veel dank daarvoor. Omdat Roy tevens de onmis- 
bare schakel met onze Vlaamse collegae was, prijzen wij ons gelukkig dat we met ingang van dit jaar Griet Peeraer, werkzaam bij de Universiteit van Antwerpen, bereid hebben gevonden toe te treden tot de redactie. Tevens verwelkomen we Debbie Jaarsma als nieuw redactielid; zij is werkzaam bij de Universiteit van Utrecht, faculteit Diergeneeskunde.

Ik wens $u$ veel leesplezier met deze $28^{\text {ste }}$ jaargang van het TMO.

\section{Jan Borleffs}

\section{Literatuur}

1. The CanMEDS 2005 Physician Competency Framework, 2005: http://meds.queensu.ca/medicine/ obgyn/pdf/CanMEDS2005.booklet.pdf

2. Papadakis MA, Teherani A, Banach MA, Knettler TR, Rattner SL, Stern DT et al. Disciplinary action by medical boards and prior behavior in medical school. New Engl J Med 2005;353:26732682.

3. Urlings-Strop LC, Themmen APN, Stijnen T, Splinter TAW. Prestaties van geselecteerde versus ingelote studenten in de preklinische en klinische fase. Congresboek NVMO congres 2008, Abstract nr. B13.1 [Effect of pre-entry selection on study success in preclinical and clinical phases of medical training. Abstracts of Conference of Netherlands Association of Medical Education, 2008, nr. B13.1].

4. Molenaar WM, Zanting A, van Beukelen P, de Grave W, Baane JA at al. A framework of teaching competencies across the medical education continuum. Med Teach 2009, in press.

5. Morrison J. Clinical governance - implications for medical education. Med Educ 1999;33:162164. 